\title{
Diverse spaces of childhood and youth: gender and other socio-cultural differences
}

Article

Accepted Version

Evans, R. and Holt, L. (2011) Diverse spaces of childhood and youth: gender and other socio-cultural differences. Children's Geographies, 9 (3-4). pp. 277-284. ISSN 1473-3277 doi: https://doi.org/10.1080/14733285.2011.595902 Available at https://centaur.reading.ac.uk/22706/

It is advisable to refer to the publisher's version if you intend to cite from the work. See Guidance on citing.

To link to this article DOI: http://dx.doi.org/10.1080/14733285.2011.595902

Publisher: Routledge

All outputs in CentAUR are protected by Intellectual Property Rights law, including copyright law. Copyright and IPR is retained by the creators or other copyright holders. Terms and conditions for use of this material are defined in the End User Agreement.

www.reading.ac.uk/centaur

\section{CentAUR}


Central Archive at the University of Reading

Reading's research outputs online 
Children's Geographies Special Issue

\title{
Editorial
}

\section{Diverse spaces of childhood and youth: gender and other socio-cultural differences}

\section{Ruth Evans and Louise Holt}

\author{
Ruth Evans \\ Department of Geography \& Environmental Science \\ University of Reading \\ Whiteknights PO Box 227 \\ Reading RG6 6AB \\ UK \\ r.evans@ reading.ac.uk \\ Louise Holt \\ Department of Geography \\ Loughborough University \\ Loughborough \\ Leicestershire \\ LE11 3TU \\ 1.holt@1boro.ac.uk
}

The papers that comprise this double special issue emerged from the Second International Conference on Geographies of Children, Youth and Families on the theme of 'Diverse childhoods in international contexts: gender and other social and cultural differences', held at the Universitat Autònoma de Barcelona from 16 to 18 July 2009 (reported in Baylina and Prats Ferret, 2010). The conference aimed to enhance geographical conceptualisations of childhood and youth by seeking to more fully understand children's and young people's lives in their diverse socio-spatial contexts and focusing on diversity, particularly gender and other social and cultural differences.

Geographers have commented on the rapid growth of geographies of children, youth and families in recent years. Important questions have been raised about the scope and scale of research being conducted, about theoretical debates and the direction of the sub-field and its status within the wider discipline (Horton and Kraftl, 2006a; Hopkins and Pain, 2007; Vanderbeck, 2008; Ansell, 2009). Pivotal here are issues surrounding the forging of children's geographies as a distinctive sub-disciplinary field and the extent to which geographies of children and youth are informed by and influence theoretical debates in the broader discipline (Horton and Kraftl, 2006a; also Beale, 2006; Holt and Costello, 2011). The issue of ghettoisation of children's geographies has also meant that the bulk of geography and the social sciences continues to deploy uncritical 'common sense' ideas and

CRuth Evans and Louise Holt, 2011. Please cite as: Evans, R. and Holt, L. (2011) 'Diverse spaces of childhood and youth: gender and other socio-cultural differences', Children's Geographies, Special Issue Editorial, 9 (3/4). 
discourses of childhood. One way of overcoming this problem is by forging more explicit links with other critical theories within geography and the broader social sciences.

The Barcelona conference, and, consequently, this special edition, marks an attempt to bring to the fore the interconnections between geographies of children and youth and critical research emerging from studies of a host of axes of difference in a range of international contexts. The focus on difference intends to emphasise the links between geographies of children and youth and a range of political/theoretical approaches, from feminism, critical studies of race/ethnicity to queer theory and post-colonialism (and so on), to enhance critical dialogue. The particular emphasis on gender reflects the dual positioning of the organisers at the Universitat Autònoma de Barcelona as feminists and geographers of childhood and youth. The papers in the special edition build upon a bourgeoning body of work that provides critical insights into the influence of gender and other socio-cultural differences in the lives of children and youth in both minority and majority world contexts (James and Prout, 1997; Cahill, 2000; Skelton, 2000; Panelli, 2002; Tucker, 2003; Jenks, 2004; Thorne, 2004; Hopkins, 2006; Katz, 2004; Punch, 2001; Robson, 2004; Chant and Jones, 2005; Evans, 2006; Evans and Becker, 2009; Van Blerk, 2006; Holt, 2007; 2010; Sporton et al., 2006; Evans, 2010; Baylina et al., 2011; Hörschelmann and Colls, 2009; Hopkins et al., 2011 ${ }^{1}$ ).

Although the differentiations of childhood (Matthews, 2003) have been increasingly investigated in a host of contexts, notable gaps persist in knowledge about the diverse experiences of childhood and youth in different spaces globally. In particular, the field of children's geographies has been dominated by Anglophone researchers, therefore accounts from non-Anglophone contexts have been marginalised (see Prats et al, this issue). The Barcelona conference brought together feminists and other scholars of social difference and geographers of children, youth and families from many countries. It provided a space to further enhance understandings of the role of gender and other socio-cultural differences in conceptualising childhood and youth (and what conceptions of childhood and youth can add to critical theories of difference) in a wide range of international contexts, from beyond the Anglophone world. In addition to this special issue, the conference led to a themed issue of Documents d'Anànalisi Geografica with papers in Spanish, Catalan and English, edited by Maria Prats Ferret and Mireia Baylina (2011).

The papers in this issue reflect the focus of the conference on diversity in a range of ways. Many of the papers explicitly focus on the influence of gender, age and other embodied socio-cultural identifications and differences, such as race, ethnicity and migration trajectories, in the everyday lives of children and youth. These accounts also suggest how gender and other social differences are experienced in specific ways by children and young people, rather than by adults who are the focus of the majority of feminist accounts, for instance. The papers thus enhance accounts of feminism and other political/theoretical projects that engage with socio-cultural differences.

Importantly, the papers also provide insights into how differentiated childhoods are experienced in specific places in international contexts that have been relatively marginalised

(ORuth Evans and Louise Holt, 2011. Please cite as: Evans, R. and Holt, L. (2011) 'Diverse spaces of childhood and youth: gender and other socio-cultural differences', Children's Geographies, Special Issue Editorial, 9 (3/4). 
within geographies of children, youth and families to date. These include such diverse urban environments as Istanbul, Copenhagen, Helsinki, Toronto, London and Bratislava and the contrasting rural settings of Ghana and England. A viewpoint by Maria Prats Ferret, Mireia Baylina and Anna Ortiz Guitart also provides an overview of the status of children's geographies in Southern Europe (Greece, Italy, Portugal and Spain). In addition, many of the papers highlight how the spatialities of childhood are interwoven with particular temporalities. Attention is given to different temporalities, from an often overlooked historical approach to the contemporary everyday rhythms of children's mobilities across cities or rural spaces.

While all the papers are linked to the overall theme of 'diverse spaces of childhood and youth: gender and other socio-cultural difference', they also encompass a number of contemporary sub-themes of particular interest to geographers that speak to recent debates about the direction and concerns of children's geographies (Horton and Kraftl, 2006a; Hopkins and Pain, 2007; Ansell, 2009). We emphasise seven intersecting themes emerging from the papers which are of current interest to geographers of children and youth: intersectionality; the importance of friendships and everyday sociality in the creation both of positive senses of identity and the insidious operation of power; mobilities and movements in the forging of (racialised) youth identities; the importance of everyday practices, performances (and therefore the mundane, the material and temporality); heterogeneous ruralities in different international contexts; how discourses of childhood intersect with difference (with an emphasis on risk and risky-ness); young people's differential participation and the methodological questions raised by researching the impact of discourses and (parental) perceptions of childhood and youth. These emergent themes frame our discussion of the papers in the special issue.

One key theme that can be identified is that of intersectionality. Building on feminists' earlier work, Hopkins and Pain (2007), Valentine (2007) and others have identified intersectionality as a useful concept for understanding the complex ways that age intersects and interacts with other markers of social difference such as gender, class, race, disability, sexuality and so on. Most of the papers in this collection, either explicitly or implicitly, explore the ways that the everyday lives, social networks and identities of children and youth are shaped by the intersection of age with gender and other socio-cultural differences.

A second theme of current interest which is developed in the special issue is that of friendships as a mechanism of the insidious and productive, along with more exclusionary, operations of power (Dyson, 2010; Bowlby, in press). Children's friendships and social networks play a central role in their ongoing negotiation of embodied gendered and racialised identities, practices and interactions within the different settings of the home, neighbourhood, school and community spaces. As Skelton and Bunnell (2011) have observed, while friendships are important in terms of individual emotional wellbeing and in enabling 'boundary crossing socio-spatial relations', they may also reinforce geographies of exclusion.

(ORuth Evans and Louise Holt, 2011. Please cite as: Evans, R. and Holt, L. (2011) 'Diverse spaces of childhood and youth: gender and other socio-cultural differences', Children's Geographies, Special Issue Editorial, 9 (3/4). 
Several papers in this collection examine how friendships enable children to navigate gendered and age-related expectations and cultural and racial diversity within particular places.

For instance, Matej Blazek's paper explores how place and gender matter to the formation of children's friendships in neighbourhood spaces in Bratislava, within the broader landscape of post-socialist East and Central Europe. The particular spatial and socio-economic characteristics of the neighbourhood emerge as significant, while children's practices and friendships appear to cut across gender and age divides. Age and gender, however, represent significant factors in young people's transitions to adolescence, which are associated with increased everyday mobilities, changing household and childcare responsibilities and more sexualised relationships with young people of the opposite sex.

The theme of friendships is also apparent in Caitriona Ni Laoire's research with children from Irish return migrant families. Ni Laoire reveals how gender and age-related norms, identities and practices are reproduced through narratives of sport, integration and friendship. She argues that gender both reinforces and undermines other axes of sameness and difference and shapes the accumulation of symbolic and social capital for return migrant children, depending on the specific articulation of gendered discourses, norms and institutions in the children's worlds before and after migration. In the contrasting migration context of young unaccompanied asylum seekers and refugees in London, Karen Wells' paper explores the importance of place and gender in shaping young people's entry into and formation of social networks that provide emotional and material support. While informal social networks and friendships were crucial to young people's migration journeys and everyday social worlds as young refugees living in London, many of these networks were sustained through contact with a range of institutions across the city. As Wells concludes, this 'confirms the strength of weak ties for connecting people to new networks that have the potential to change their social position and cultural location', and highlights the importance of formal ties in facilitating access to material and cultural resources.

Alongside the importance of friendship and social networks to children's identities and practices, Ni Laoire's and Wells' papers also point to migration, mobilities and (how they are interwoven with) processes of racialisation as important socio-cultural markers of difference that shape the everyday lives of children and youth as part of the ongoing process of social becoming (see also Holt and Costello, 2011; Hopkins et al., 2011; Thomas, 2005; Valentine and Sporton, 2009).

Seeking to explore the ways that intersectional identities and historical migrations are embodied, Rosa Mas Giralt's paper discusses the racialised identifications and peer interactions of young people of Latin American descent living in the North of England. Within the context of limited possibilities of developing collective identifications with a distinctive cultural group locally, Mas Giralt argues that young people deploy strategies of

(CRuth Evans and Louise Holt, 2011. Please cite as: Evans, R. and Holt, L. (2011) 'Diverse spaces of childhood and youth: gender and other socio-cultural differences', Children's Geographies, Special Issue Editorial, 9 (3/4). 
'invisibility' and 'visibility' in their everyday embodied interactions to reproduce sameness and negotiate belonging to the multi-ethnic environments in which they live.

Although the papers by Wells, Ni Laoire and Mas Giralt frame children's experiences within the global context of transnational migration, such 'large scale' movements through space are only made possible through ongoing everyday mobilities at the 'local scale' (see also Holt and Costello, 2011). Indeed, these papers reveal how migrant children's lives are characterised by diverse movements, social ties and interactions in their neighbourhoods, schools, families and through transnational and virtual communities. As large scale movements through space, transnational migration experiences continue to influence the individual and collective identifications of young people (and adults), embodied and enacted through their everyday performances, social interactions and mobilities in and across diverse racialised settings.

Several papers in this collection further our understandings of the mundane everyday rhythms of children and young people's lives, with a particular focus on mobilities and journeys through time and space. These papers address Horton and Kraftl's (2006b) call to explore the mundane, everyday events, 'happenings' and ongoing practices in children's lives. In particular, the papers address the suggestion that, 'greater attention to the sheer variety of these doings, with the focus turned sharply on those issues that matter to diverse groups of children, will inevitably allow 'Children's Geographers' to 'talk back' to wider contemporary theorisations of performance, performativity, everydayness and practice' (p. 87). Kim Kullman and Charlotte Palludan draw on Henri Lefebvre's 'rhythmanalytical' approach to conceptualise the school journeys of pre-school pupils in Copenhagen, Denmark and those of primary school pupils in Helsinki, Finland. This approach enables the authors to sketch out children's embodied experiences of diverse temporal repetitions and variations of the school journey and explore the diverse ways that children respond to these rhythms and exercise their agency. The authors argue that the research reveals 'how entangled children are with their surroundings, constantly shifting their capacities to act through encounters with other bodies, technologies and practices'.

Two departure points can be traced from the emphasis on material co-presences and everyday life. First, the focus on the everyday sensitises Kullman and Palludan to the importance of temporality to the experiences of young people, addressing recent critical attention to how space is timed and time is spaced (Massey, 2005; Jones, 2009). A different kind of temporality is the emphasis of Elizabeth Brown's paper, which highlights that representations and ideas of childhood and youth are historically as well as geographically contingent. The paper draws upon analysis of archival material on the Seattle Juvenile Court to provide critical insights into the construction of the 'unchildlike child' and the moral cartography of Seattle in the first quarter of the $20^{\text {th }}$ Century, as delinquency came to be defined 'as the product of individual failing, family inadequacies and racial and class deviance'.

(CRuth Evans and Louise Holt, 2011. Please cite as: Evans, R. and Holt, L. (2011) 'Diverse spaces of childhood and youth: gender and other socio-cultural differences', Children's Geographies, Special Issue Editorial, 9 (3/4). 
Second, this focus emphasises the importance of materiality. A focus on the daily habits, repetitions and rhythms of children's lives responds to recent work emphasising the potential contribution that children's geographers could make to materialist approaches and nonrepresentational theories, 'things that go on and on and on in the background' (Horton and Kraftl, 2006b, p.259; Ansell, 2009). Phoebe Foy-Phillips and Sally Lloyd-Evans' paper also directly answers this call by exploring how materiality shapes social relations, parenting cultures and children's mobility in the 'English rural idyll'. Research with working and middle class mothers in the South West of England reveals that the use of the car and the physical layout of villages combined with gendered and classed performances of motherhood and childhood to play a significant role in determining parenting cultures and children's use of public space. This results in perceptions of risk that restrict children's mobilities, including their independent journeys to school.

Gendered rural childhood and youth and the school journey also represent a key concern of the paper by Gina Porter Kate Hampshire, Albert Abane, Augustine Tanle, Kobina EsiaDonkoh, Regina Obilie Amoako-Sakyi, Samuel Agblorti and Samuel Asiedu Owusu, in the contrasting setting of rural Ghana. Linking the implications of the 'transport gap' and distance to school in rural Sub-Saharan Africa to gendered expectations of children's household contributions and other barriers to education, the paper demonstrates that girls in rural Ghana are more likely than boys to miss school, arrive late and be punished, and experience sexual harassment and early pregnancy. This means that girls are less likely than boys to complete primary school or to continue their education at secondary school. Reduced access to education, gendered workloads and restricted mobility prevent young women from developing the social networks that would help them to secure more sustainable livelihoods, while young men are more able to pursue livelihood opportunities in the city. Such gender inequalities in access to education and livelihood options and gendered constructions of young women's place in the rural family home until marriage has implications for achieving global development targets in relation to universal access to primary education and reducing the intergenerational transmission of poverty. The micro-geographies of young people's school journeys are thus clearly linked to wider policy concerns at the global level.

Sensitivity to time and space along with gender and other social differences can nuance understandings of how discourses of childhood as angels or devils, as a risk or at risk, emerge in specific contexts in space-time and are applied heterogeneously to children according to other axes of power (gender, race, ethnicity, class, sexuality, and so on). Risk and riskiness emerge as a specific theme in many of the papers (see Pain, 2006; Colozzi and Giovannini, 2003). As discussed above, Brown's paper highlights how discourses of risk, riskiness and family inadequacy were intertwined with class, race and ethnicity in early $20^{\text {th }}$ century Seattle. Jenny Parkes and Anna Connolly analyse the shifting, sometimes contradictory discursive representations of young people in an urban neighbourhood in the UK with high levels of youth crime and social deprivation. While professionals strove to avoid stereotypical representations of youth as 'risky', the authors argue that gendered, racialised and classed

(CRuth Evans and Louise Holt, 2011. Please cite as: Evans, R. and Holt, L. (2011) 'Diverse spaces of childhood and youth: gender and other socio-cultural differences', Children's Geographies, Special Issue Editorial, 9 (3/4). 
stereotypes of youth emerged in discourses of 'deficit families' and the 'deficit neighbourhood'. Young people drew on notions of 'risky' or 'at risk' youth, but also revealed instances of resistance, particularly in relation to police harassment and restrictions on their freedom of movement in the neighbourhood.

Parental perceptions of risk also influenced children's peer interactions, outdoor play and mobilities in Elçin Tezel's case study of gated communities in Istanbul. Although the communal areas of gated communities were perceived by mothers as a safer environment for children to play unsupervised with their peers than elsewhere in the city and were often preferred by wealthier families for this reason, the study found that children's opportunities for active free play within the secured courtyard were impeded by parental safety concerns. As children grew older, they had more opportunities to meet their friends unsupervised in communal courtyards, although they were still subject to adults' gaze to some extent within the gated community.

The study raises pertinent questions that children's geographers have been asking for some time about the extent to which urban planning takes into consideration the views and experiences of children and youth about spaces designed for their benefit. The challenges of young people's participation in urban planning, architecture and regeneration are underpinned by long-standing concerns of childhood researchers and children's rights proponents about the importance of recognising that children and youth are social actors who have a right to express their views about all matters that affect them, as outlined in the UN Convention on the Rights of the Child. The emphasis on the differentiation of childhood raises important questions about the extent to which children and young people from different socio-cultural and class backgrounds are able to exercise their agency and participate in broader contexts, institutions and policy initiatives, such as urban planning, housing developments, educational spaces and programmes to tackle youth crime and social exclusion.

Indeed, focusing on the experiences of ethnically diverse, socio-economically excluded young people, Danielle Leahy Laughlin and Laura Johnson's paper explicitly juxtaposes young people's definitions and perceptions of public space with public housing regeneration plans drawn up by adult planners in Regent Park, Toronto. The authors argue that young people define public space from the perspective of a sense of belonging rather than ownership and call for planners to give explicit consideration to young people's views in order to achieve 'more cohesive community public spaces'. Rosie Parnell and Maria Patsarika's paper provides an interesting case study of the challenges of achieving inclusion and diversity of representation in policy initiatives designed to involve young people. The Building Schools for the Future initiative, introduced by the Labour government in 2004, aimed to rebuild or renew all of England's state secondary schools in consultation with staff, pupils and the wider community. The research suggests that analysing the interaction between inclusive (or not) practices and the ways power relations are manifested spatially is crucial for policymakers,

CRuth Evans and Louise Holt, 2011. Please cite as: Evans, R. and Holt, L. (2011) 'Diverse spaces of childhood and youth: gender and other socio-cultural differences', Children's Geographies, Special Issue Editorial, 9 (3/4). 
educationalists and participation practitioners in order to ensure that young people's views influence decision-making processes. These findings have resonance to any endeavour to include children's voices in planning.

Young people's participation and political change for children and youth should not however be limited to 'the spaces conceded for children's participation', since as Ansell (2009, p.205) argues, 'change is needed for children now, in spaces and in policy areas that do not, and perhaps cannot, directly admit children's voices'. Ansell calls for a relational approach, recognising that 'children's lives are produced through interaction with others'. Indeed, the papers in this collection respond to some extent to concerns expressed about the "parochial locus of interest' of geographies of children and youth to date and the need to expand the scope of research beyond the 'micro-scale' and the limits of children's 'perceptual fields'(ibid, p.202).

While the majority of papers investigate young people's direct experiences and perspectives (in common with the vast majority of work in the sub-field of geographies of children and youth), several papers analyse discursive representations of childhood and youth, which conventionally have had less 'place' within children's geographies. The papers by FoyPhillips and Lloyd-Evans, Tezel, and Parkes and Connolly, for example, are based on research with mothers or professionals and reveal adult perspectives and restrictions on children's mobilities and risks. Papers, such as those by Parnell and Patsarika, Tezel and Leahy Laughlin and Johnson, have clear implications for policy and practice relating to the lives of children and youth, at a variety of intersecting scales. These papers raise methodological questions for geographies of children and youth.

Adults' perceptions of their children and wider discourses about childhood have a significant impact on the way that childhoods are lived and experienced. Children (like adults) are not sovereign actors; they cannot survey all the ways in which they are implicated in power and constrained or enabled in the choices they make (Gallacher and Gallagher, 2008). Therefore, it is pertinent to explore how children's and young people's lives are structured along with engaging with children's voices. The sub/inter-disciplinary field of children's geographies is a collective endeavour, with studies that focus on children's voices and those that emphasise how children's lives are structured from without together potentially providing important insights into the geographies of children and young people. To date, studies of children's own voices and experiences have dominated the field.

We believe, and we hope that the reader finds, that the papers in the special edition individually and taken collectively, make an important contribution to the field of children's geographies. The gaze is turned to groups and issues that have been hitherto neglected within the field. Important here is the engagement with the non-Anglophone world along with insights that engage with, enhance and take forward some key conceptual, theoretical and

(CRuth Evans and Louise Holt, 2011. Please cite as: Evans, R. and Holt, L. (2011) 'Diverse spaces of childhood and youth: gender and other socio-cultural differences', Children's Geographies, Special Issue Editorial, 9 (3/4). 
methodological debates in the sub-discipline of geographies of children and youth, in the discipline of geography, and beyond.

\section{Notes}

1. The references here are an attempt to convey the diversity of existent research that could be couched within this theme and are not an exhaustive list.

\section{Acknowledgements}

We wish to thank Maria Prats Ferret, Mireia Baylina, Anna Ortiz Guitart and M. Dolors Garcia Ramon and colleagues for hosting and organising such a successful Second International Conference on Geographies of Children, Youth and Families at the Universitat Autònoma de Barcelona in July 2009. We are grateful to Hugh Matthews for his support and to all the authors for their excellent contributions to this special issue.

\section{References}

Ansell, N., 2009. Childhood and the politics of scale: descaling children's geographies? Progress in Human Geography, 33(2), 190-209.

Baylina, M., Guitart, A. and Prats, M., 2011. Children living in the city: gendered experiences and desires in Span and Mexico. In L. Holt ed. Geographies of Children, Youth and Families: an International Perspective. London: Routledge, 153-166.

Baylina, M. and Prats Ferret, M., 2010. The Second International Conference on Geographies of Children, Youth and Families, Barcelona 2009: a Report. Viewpoints, Children's Geographies, 8(4), 437-440.

Beale N., 2006. The practicalities of theory: engagement, relevance and application. Children's Geographies, 4, 219-224.

Bowlby, S., In press. Friendship, co-presence and care: neglected spaces, Social and Cultural Geography, Special issue on Care of the Body: Spaces of Practice.

Cahill, C., 2000. Street Literacy: urban teenagers' strategies for negotiating their neighbourhood. Journal of Youth Studies, 3, 251 - 277.

Chant, S. and Jones, G., 2005. Youth, gender and livelihoods in West Africa: perspectives from Ghana and The Gambia. Children's Geographies, 3, 185-99.

(C) Ruth Evans and Louise Holt, 2011. Please cite as: Evans, R. and Holt, L. (2011) 'Diverse spaces of childhood and youth: gender and other socio-cultural differences', Children's Geographies, Special Issue Editorial, 9 (3/4). 
Colozzi, I.. and Giovannini, G., eds. 2003. Young People in Europe: Risk, Autonomy and Responsibilities. Milano: Franco Angeli.

Dyson, J., 2010. Friendship in practice: girls' work in the Indian Himalayas. American Ethnologist, 37(3), 482-498.

Evans, B., 2010. Anticipating fatness: childhood, affect and the pre-emptive "war on obesity". Transactions of the Institute of British Geographers, 35, 21-38.

Evans, R., 2006. Negotiating social identities: the influence of gender, age and ethnicity on young people's “street careers" in Tanzania. Children's Geographies, 4(1), 109-128.

Evans, R. and Becker, S., 2009. Children Caring for Parents with HIV and AIDS: Global Issues and Policy Responses. Bristol: The Policy Press.

Gallacher, L.A. and Gallagher, M., 2008. Methodological immaturity in childhood research: thinking through 'participatory methods'. Childhood, 15, 499-516.

Holt, L., 2007. Children's socio-spatial (re)production of disability in primary school playgrounds. Environment and Planning D: Society and Space, 25, 783-802.

Holt, L., 2010. Young people's embodied social capital and performing disability. Children's Geographies, 8, 25 - 37

Holt, L. and Costello, L., 2011. Beyond otherness: exploring diverse spatialities and mobilities of childhood and youth populations. Population, Space and Place, 17, n/a. doi:10.1002/psp.621.

Holt, L. 2011. Geographies of Children, Youth and Families: International Perspectives. In: L. Holt, ed. Geographies of Children, Youth and Families: International Perspectives. Routledge, 1-8.

Hopkins, P., 2006. Youthful Muslim masculinities: gender and generational relations. Transactions of the Institute of British Geographers, 31, 337-52.

Hopkins, P. and Pain, R., 2007. Geographies of age: thinking relationally. Area, 39, 287-94.

Hopkins P., Olson E., Pain R., Vincett, G., 2011. Mapping intergenerationalities: the formation of youthful religiosities. Transactions of the Institute of British Geographers, 36(2), 314-327.

Hörschelmann, K. and Colls, R., eds. 2010. Contested Bodies of Childhood and Youth, London: Palgrave MacMillan.

Horton, J. and Kraftl, P., 2006a. What else? Some more ways of thinking and doing 'children's geographies'. Children's Geographies, 4(1), 69-95.

(CRuth Evans and Louise Holt, 2011. Please cite as: Evans, R. and Holt, L. (2011) 'Diverse spaces of childhood and youth: gender and other socio-cultural differences', Children's Geographies, Special Issue Editorial, 9 (3/4). 
Horton, J. and Kraftl, P., 2006b. Not just growing up, but going on: materials, spacings, bodies, situations. Children's Geographies, 4(3), 259-276.

James, A. and Prout, A., eds. 1997. Constructing and Reconstructing Childhood, London: Falmer Press.

Jenks, C., 2004. Many childhoods?, Childhood, 11(1), 5-8.

Jones, M., 2009. Phase space: geography, relational thinking, and beyond. Progress in Human Geography, 33(4), 487-506.

Katz, C., 2004. Growing up Global: Economic Restructuring and Children's Everyday Lives, Minneapolis: University of Minnesota Press.

Massey, D., 2005 For Space, London: Sage.

Matthews, H., 2003. Inaugural editorial: Coming of age for children's geographies.

Children's Geographies, 1, 3-5.

Pain, R., 2006. Paranoid parenting? Rematerializing risk and fear for children. Social and Cultural Geography, 7, 221-243.

Panelli, R., 2002. Editorial: Young rural lives: strategies beyond diversity. Journal of Rural Studies, 18, 113-22.

Prats Ferret, M. and Baylina, M., 2011. Presentació. Geografies de la infància, la joventut i les famìlies. Documents d'Anàlisi Geogràfica, 57(1), 5-9.

Punch, S. 2001. Household division of labour: generation, gender, age, birth order and sibling composition. Work, Employment and Society, 15, 803-23.

Pyer, M., Horton, J., Tucker, F., Ryan, S. and Kraftl, P., 2010. Children, young people and 'disability': challenging children's geographies? Children's Geographies, 8(1), 1-8.

Robson, E., 2004. Children at work in rural northern Nigeria: patterns of age, space and gender. Journal of Rural Studies, 20, 193-210.

Skelton, T., 2000. 'Nothing to do, nowhere to go?': teenage girls and 'public' space in the Rhondda Valleys, South Wales. In: S. Holloway and G. Valentine (eds) Children's Geographies: Playing, Living, Learning, London: Routledge, 80-99.

Skelton, T. and Burnell, T., 2011. 'Geographies of friendships.' call for papers for the RGSIBG 2011 Annual Conference Session, 21 January.

Sporton, D., Valentine, G. and Nielsen, K., 2006. Post conflict identities: Affiliations and practices of Somali asylum seeker children. Children's Geographies, 4(2), 203-217.

(CRuth Evans and Louise Holt, 2011. Please cite as: Evans, R. and Holt, L. (2011) 'Diverse spaces of childhood and youth: gender and other socio-cultural differences', Children's Geographies, Special Issue Editorial, 9 (3/4). 
Thomas, M.E., 2005. 'I think it's just natural': the spatiality of racial segregation at a US high school. Environment and Planning A, 37, 1233 - 1248.

Thorne, B., 2004. Theorizing age and other differences. Childhood, 11(4), 403-408.

Tucker, F., 2003. Sameness or difference? Exploring girls' use of recreational space. Children's Geographies, 1, 111-124.

Van Blerk, L., 2006. Diversity and difference in the everyday lives of Ugandan street children: the significance of age and gender for understanding the use of space. Social Dynamics, 32(1), 47-74.

Vanderbeck, R., 2008. Reaching critical mass? Theory, politics and the culture of debate in children's geographies, Area, 40(3), 393-400.

Valentine, G., 2007. Theorizing and Researching Intersectionality: A Challenge for Feminist Geography. The Professional Geographer, 59, 10-21.

Valentine, G. and Sporton, D., 2009. 'How other people see you, it's like nothing that's inside'. The impact of processes of disidentification and disavowal on young people's subjectivities. Sociology, 43(4), 735-751.

(C) Ruth Evans and Louise Holt, 2011. Please cite as: Evans, R. and Holt, L. (2011) 'Diverse spaces of childhood and youth: gender and other socio-cultural differences', Children's Geographies, Special Issue Editorial, 9 (3/4). 